\title{
The prescription of medical cannabis by a transitional pain service to wean a patient with complex pain from opioid use following liver transplantation: a case report
}

\section{Prescription de cannabis thérapeutique par un service de prise en charge transitoire de la douleur afin de sevrer un patient souffrant de douleur complexe de sa consommation d'opiö̈des après une greffe hépatique: une présentation de cas}

\author{
Howard Meng, MD · John G. Hanlon, MD · Rita Katznelson, MD · Anand Ghanekar, MD, PhD • \\ Ian McGilvray, MD, PhD • Hance Clarke, MD, PhD \\ Received: 6 July 2015 / Revised: 16 September 2015/Accepted: 15 October 2015/Published online: 27 October 2015 \\ (C) Canadian Anesthesiologists' Society 2015
}

\begin{abstract}
Purpose The purpose of this case report is to describe a patient with a preoperative complex pain syndrome who underwent liver transplantation and was able to reduce his opioid consumption significantly following the initiation of treatment with medical cannabis.
\end{abstract}

Dr. John G. Hanlon is an advisor to Canvas Rx, a medical cannabis counselling service. No other authors have any conflicts of interest.

Author contributions Howard Meng and Hance Clarke were involved in drafting the manuscript. John G. Hanlon, Rita

Katznelson, Anand Ghanekar, and Ian McGilvray contributed to the manuscript.

H. Meng, MD - J. G. Hanlon, MD · R. Katznelson, MD .

H. Clarke, MD, PhD

Department of Anesthesia, University of Toronto, Toronto, ON, Canada

J. G. Hanlon, MD

Department of Anesthesia, St. Michael's Hospital, Toronto, ON, Canada

R. Katznelson, MD $\cdot$ H. Clarke, MD, PhD ( $ه)$

Pain Research Unit, Department of Anesthesia and Pain

Management, Toronto General Hospital, 200 Elizabeth Street,

Eaton North 3 EB 317, Toronto, ON M5G 2C4, Canada

e-mail: hance.clarke@utoronto.ca

R. Katznelson, MD - H. Clarke, MD, PhD

Transtional Pain Service, Toronto General Hospital, Toronto,

ON, Canada

A. Ghanekar, $\mathrm{MD}, \mathrm{PhD} \cdot \mathrm{I}$. McGilvray, $\mathrm{MD}, \mathrm{PhD}$

Division of General Surgery, University Health Network,

Toronto, ON, Canada
Clinical features A 57-yr-old male with a history of hepatitis $C$ cirrhosis underwent liver transplantation. Preoperatively, he was taking hydromorphone 2-8 $m g \cdot d a y^{-1}$ for chronic abdominal pain. Postoperatively, he was given intravenous patient-controlled analgesia through which he received hydromorphone $30{\mathrm{mg} \cdot d a y^{-1}}^{\text {. Our }}$ multidisciplinary Transitional Pain Service was involved with managing his moderate to severe acute postsurgical pain in hospital and continued with weaning him from opioid medications after discharge. It was difficult to wean the patient from opioids, and he was subsequently given medical cannabis at six weeks postoperatively with remarkable effect. By the fifth postoperative month, his use of opioids had tapered to $6 \mathrm{mg} \cdot \mathrm{day}^{-1}$ of hydromorphone, and his functional status was excellent on this regimen.

Conclusion Reductions in opioid consumption were achieved with the administration of medical cannabis in a patient with acute postoperative pain superimposed on a chronic pain syndrome and receiving high doses of opioids. Concurrent benefits of initiating medical cannabis may include improvements in pain profile and functional status along with reductions in opioid-related side effects. This highlights the potential for medical cannabis as an adjunct medication for weaning patients from opioid use.

\section{Résumé}

Objectif L'objectif de cette présentation de cas était de décrire un patient souffrant d'un syndrome préopératoire de douleur complexe et ayant subi une greffe hépatique, qui a été capable de réduire sa consommation d'opiö̈des 
de façon significative après la mise en place d'un traitement à base de cannabis thérapeutique.

Éléments cliniques Un homme de 57 ans présentant des antécédents de cirrhose liée à une hépatite $C$ a subi une greffe hépatique. Avant l'opération, il prenait 2-8 $m g \cdot$ jour $^{-1}$ d'hydromorphone pour traiter une douleur abdominale chronique. Après l'opération, on lui a prescrit une analgésie contrôlée par le patient intraveineuse par laquelle il recevait $30{\mathrm{mg} \cdot j o u r^{-1}}^{-1}$ d'hydromorphone. Notre service de prise en charge transitoire de la douleur, une équipe pluridisciplinaire, était responsable de la prise en charge sa douleur postchirurgicale modérée à très sévère à l'hôpital et a continué à le sevrer de ses médicaments opiö̈des après son congé. Le sevrage des opiödes étant difficile, du cannabis thérapeutique a été prescrit au patient par la suite pour une durée de six semaines après l'opération, avec un effet remarquable. Au cinquième mois postopératoire, sa consommation d'opiö̈des avait baissé à $6{\mathrm{mg} \cdot j o u r^{-1}}^{-1}$ d'hydromorphone, et son statut fonctionnel était excellent sous ce régime posologique.

Conclusion La consommation d'opiö̈des a pu être réduite grâce à l'administration de cannabis thérapeutique chez un patient souffrant de douleur postopératoire aiguë superposée à un syndrome de douleur chronique et recevant de fortes doses d'opiö̈des. Parmi les autres avantages potentiels d'un traitement au cannabis thérapeutique, citons une amélioration du profil de douleur et du statut fonctionnel ainsi qu'une réduction des effets secondaires liés aux opiö̈des. Ce compte rendu souligne le potentiel du cannabis thérapeutique en tant que médicament adjuvant pour sevrer les patients d'une utilisation d'opiö̈des.

Dried cannabis, a preparation derived from the Cannabis sativa or indica plant, has been used in traditional medicine for centuries as a treatment for various conditions. These conditions included but were not limited to pain, muscle spasm, nausea, vomiting, and depression. ${ }^{1,2}$ More recently, with improved understanding of endogenous cannabinoid pathways and increased advocacy from various patient groups, cannabis has resurfaced as a potential analgesic adjunct.

There is currently a paucity of data in the literature addressing the efficacy of cannabis as an adjunct for weaning patients from opioids. In this case report, a patient with acute postoperative pain superimposed on a chronic pain syndrome following liver transplantation had his opioid consumption successfully reduced after initiation of treatment with medical cannabis.

\section{Case}

Written informed consent was obtained from the patient for publication of this report. A 57-yr-old male (weight $98 \mathrm{~kg}$, height $185 \mathrm{~cm}$ ) with blood transfusion-related hepatitis $\mathrm{C}$ and subsequent development of hepatocellular carcinoma (HCC) presented for liver transplantation. His hepatitis was complicated by ascites and esophageal varices. His medical history was otherwise remarkable for insulin-dependent diabetes mellitus and remote back and tonsillectomy operations.

Prior to liver transplantation, he suffered from a complex chronic pain syndrome for the past four years that manifested as a mix of dull and sharp pains in his abdomen. The pain averaged five points on a ten-point visual analogue pain scale (VAS; $0=$ no pain, $10=$ worst pain imaginable), with its worst at six points. He had previously tried codeine and acetaminophen-codeine combinations but without adequate relief. $\mathrm{He}$ was subsequently treated with hydromorphone averaging 2-8 mg.day ${ }^{-1}$

Following an uncomplicated liver transplant operation, he was followed by our Acute Pain Service and managed on hydromorphone intravenous patient-controlled analgesia (PCA) on the ward. His PCA was discontinued on postoperative day (POD) 4. He was subsequently switched to hydromorphone extended-release $3 \mathrm{mg}$ po bid and hydromorphone immediate-release $4 \mathrm{mg} q 3 \mathrm{~h} \mathrm{prn}$, which he consistently used.

While in hospital, he developed worsening pain in his lower back without radiation to his legs and with no paresthesia. His VAS postoperatively ranged from 5-8/10 and required upwards of $40 \mathrm{mg} \cdot \mathrm{day}^{-1}$ of hydromorphone. As a result of his increased acute postoperative pain, he was referred to our multidisciplinary Transitional Pain Service (TPS) for help to wean him off opioids and to facilitate his return to his baseline functional status. The Short-Form McGill Pain Questionnaire (SF-MPQ-2) was administered during his TPS assessment. The SF-MPQ-2 consisted of 22 descriptors of pain $(0=$ no pain, $10=$ worst pain) separated into continuous, intermittent, neuropathic, and affective subscales. ${ }^{3}$ On POD 7 , the patient complained of his incisional pain using intense acute neuropathic pain descriptors (e.g., hot-burning 8/10 and pain caused by light touch 7/10) as well as continuous (throbbing 8/10 and gnawing 8/10) and intermittent pain descriptors (shooting $8 / 10$, stabbing $8 / 10$, sharp $8 / 10$, and splitting $8 / 10$ ). At the time of discharge (POD 11), the patient required hydromorphone extended-release $3 \mathrm{mg}$ tid and hydromorphone immediate-release $12-20 \mathrm{mg} \cdot$ day $^{-1}$ po prn. At the time of the initial TPS visit (POD 15), he had been unable to wean himself from opioids at all, and he 
described his pain as moderate to severe by the end of the day.

After discharge, he returned to work as a systems program engineer but found his mental alertness and function were too debilitated by the hydromorphone $(\geq 20$ $\mathrm{mg} \cdot \mathrm{day}^{-1}$ ). His Brief Pain Inventory (Short Form), a measure of the severity of pain impact on daily functions, indicated $\geq 8$ (on an 11-point scale) on pain interference as it relates to his general activity, mood, relations with other people, sleep, and enjoyment of life. ${ }^{4}$ The combination of acute postoperative pain and chronic pain in this patient pointed towards a complex pain state that complicates the means to wean from opioids.

Prior to surgery, the patient had frequently used cannabis for nausea secondary to his HCC as well as for relaxation and reduction of anxiety. Given the patient's positive experience with cannabis, he was interested in using medical cannabis to alleviate his postoperative pain, nausea, and malaise. The patient was counselled on the adverse effects of cannabis, including psychotropic effects, impairment of motor skills, and autonomic disturbances. He was advised to seek medical attention if these adverse symptoms impaired function.

He was prescribed cannabis $1 \mathrm{~g} \cdot$ day $^{-1}$ with follow-up three weeks later. At $\sim$ six weeks postoperatively, the patient started using medical cannabis. At $\sim$ ten weeks postoperatively, he was able to decrease his intake of hydromorphone extended-release to $3 \mathrm{mg}$ bid and hydromorphone immediate-release to a total of 8 $\mathrm{mg} \cdot \mathrm{day}^{-1} \mathrm{prn}$. By $\sim 12$ weeks postoperatively, the patient was almost able to stop his dose of hydromorphone immediate-release prn and use only $3 \mathrm{mg}$ of hydromorphone extended-release bid. On follow-up by the TPS via Telehealth appointments, he did not report any psychotropic effects while using either strains of medical cannabis or other adverse effects.

At his five-month postoperative follow-up, his global pain by VAS was $4 / 10$ on average. His pain never returned to zero but was manageable, and he was able to function well as both his incisional pain and back pain had improved. In comparison with his POD 7 assessment, his SF-MPQ-2 scores at five months were as follows: his neuropathic pain scores were drastically decreased (e.g., hot-burning 1/10 and pain caused by light touch 3/10) and his continuous (throbbing 6/10 and gnawing 5/10) pain descriptors were also reduced. Nevertheless, his intermittent pain descriptors (shooting 8/10, stabbing 8/10, sharp 8/10, and splitting 8/10) remained the same, and he identified several new neuropathic pain descriptors (i.e., numbness $8 / 10$ and tingling pain 7/10) that were not present at discharge.

With the cannabis, his nausea and malaise were well controlled and his sleep was improved. He continues to take hydromorphone extended-release $3 \mathrm{mg}$ bid with rare opioid use for treatment of breakthrough pain. The patient is now an experienced medical cannabis user and has been able to adjust the strains he uses based on the content of tetrahydrocannabinol (THC) and cannabidiol (CBD) for different purposes.

The patient primarily uses a high CBD: low THC indica dominant strain called Avidekel (THC 0.79\%, CBD $17.08 \%$ ) for analgesia and uses a higher concentration THC sativa strain called Midnight (THC 9.43\%, CBD $11.93 \%$ ) when nausea is involved (both strains from MedReleaf Corp., Markham, ON, Canada).

\section{Discussion}

This case report highlights the considerable challenges in tapering opioid consumption in postoperative patients with long-standing chronic pain. Following major surgery, patients leave the hospital requiring approximately three times more than their baseline opioid requirements. ${ }^{5}$ Tapering opioid use is paramount, especially as it is well known that high opioid consumption slows a patient's return to baseline function, while discontinuation of opioids results in less disability and improved quality of life. ${ }^{6}$ Given the limited data about opioid long-term effectiveness and our increasing recognition that dose dependency can lead to serious harm, other types of analgesic adjuvants, including cannabis, have been trialed. ${ }^{7}$

The endocannabinoid system is intricately involved in normal human physiology. Both cannabinoid receptors ( $\mathrm{CB} 1$ and $\mathrm{CB} 2$ ) have been shown to be involved in pain modulation activities. Peripheral agonist activity at these receptors has shown inhibitory effects on pain responses. $^{8,9}$

Animal studies investigating the neuroanatomical distribution of cannabinoid and opioid receptors show colocalization in nervous system tissues involved in processing painful stimuli, notably in the spinal cord, locus ceruleus, and striatum. ${ }^{10}$ Furthermore, heterodimerization of these two receptors may allow for simultaneous co-activation of CB1 and mu/kappa receptors, which potentially can activate two pathways in pain modulation. ${ }^{11}$ In rats given periaqueductal grey morphine injection, pretreatment with a synthetic cannabinoid HU-210 resulted in greater analgesic effect than morphine alone. ${ }^{12}$ More importantly, the combination of morphine and THC in rats was shown to prevent the incidence of tolerance to an even greater extent than administering the drugs independently. ${ }^{12}$ Numerous studies using the combination of opioids (morphine, codeine) and cannabinoids (THC) have been shown to have superior, potentially synergistic, analgesic effects. ${ }^{13,14}$

Postoperatively, our patient found it difficult to maintain mental alertness and function, effects that were thought to 
be secondary to opioid use. Furthermore, the patient would likely have developed opioid tolerance after several weeks of persistent high-dose consumption. With cannabis, the patient reduced his total opioid consumption of hydromorphone from $30 \mathrm{mg} \cdot \mathrm{day}^{-1}$ to $6 \mathrm{mg} \cdot \mathrm{day}^{-1}$. As a result of the reduced side effects of opioids, he has been able to resume work at home.

The reduction in opioid consumption in our patient can be partially attributed to the intrinsic analgesic properties of cannabis via binding to the $\mathrm{CB} 1$ and $\mathrm{CB} 2$ receptors. In a study examining analgesic equivalence of THC $v s$ opioid in cancer pain patients, $10 \mathrm{mg}$ and $20 \mathrm{mg}$ of oral THC were found to be equipotent to $60 \mathrm{mg}$ and $120 \mathrm{mg}$ of oral codeine, respectively. ${ }^{15}$ Although medical cannabis has not been approved by Health Canada as a therapeutic product, it has been used for pain in multiple sclerosis, chronic noncancer pain (mainly neuropathic), and severe refractory cancer-associated pain. ${ }^{16}$

In a recent randomized-controlled trial examining opioiddependent patients undergoing detoxification, the use of the cannabinoid dronabinol, used in conjunction with extendedrelease naltrexone, reduced opioid withdrawal symptoms following the initiation of treatment. Furthermore, patients who regularly smoked cannabis achieved higher retention rates in the detoxification program compared with noncannabis users. ${ }^{17}$ Cellular studies of agonist co-activation of CB1 and mu opioid receptors produced a smaller response than activation of either receptor independently. ${ }^{11}$ Partial opioid receptor activation may serve to explain the decreased incidence of withdrawal effect that our patient experienced when tapering off opioids, similar to the opioid agonist-antagonist effect of buprenorphine.

In summary, the potential opioid-sparing effect of medical cannabis is thought to occur via intrinsic analgesic effects and interplay between opioid and cannabinoid receptors. The potential for medical cannabis to reduce opioid-related side effects and improve patient function following surgery needs further study.

Conflict of interest None declared.

\section{References}

1. Kalant OJ. Report of the Indian Hemp Drugs Commission, 189394: a critical review. Int J Addict 1972; 7: 77-96.

2. Machado Rocha FC, Stefano SC, De Cassia Haiek R, Rosa Oliveira OJ, DE Silveira DX. Therapeutic use of Cannabis sativa on chemotherapy-induced nausea and vomiting among cancer patients: systematic review and meta-analysis. Eur J Cancer Care (Engl) 2008; 17: 431-43.

3. Dworkin RH, Turk DC, Revicki DA, et al. Development and initial validation of an expanded and revised version of the Shortform McGill Pain Questionnaire (SF-MPQ-2). Pain 2009; 144: $35-42$.

4. Keller S, Bann CM, Dodd SL, Schein J, Mendoza TR, Cleeland $C S$. Validity of the brief pain inventory for use in documenting the outcomes of patients with noncancer pain. Clin J Pain 2004; 20: 309-18.

5. Rapp SE, Ready LB, Nessly ML. Acute pain management in patients with prior opioid consumption: a case-controlled retrospective review. Pain 1995; 61: 195-201.

6. Kidner CL, Mayer TG, Gatchel RJ. Higher opioid doses predict poorer functional outcome in patients with chronic disabling occupational musculoskeletal disorders. J Bone Joint Surg Am 2009; 91: 919-27.

7. Chou R, Turner JA, Devine EB, et al. The effectiveness and risks of long-term opioid therapy for chronic pain: a systematic review for a National Institutes of Health Pathways to Prevention Workshop. Ann Intern Med 2015; 162: 276-86.

8. Kelly S, Jhaveri MD, Sagar DR, Kendall DA, Chapman V. Activation of peripheral cannabinoid CB1 receptors inhibits mechanically evoked responses of spinal neurons in noninflamed rats and rats with hindpaw inflammation. Eur J Neurosci 2003; 18: 2239-43.

9. Ibrahim MM, Rude ML, Stagg NJ, et al. CB2 cannabinoid receptor mediation of antinociception. Pain 2006; 122: 36-42.

10. Salio C, Fischer J, Franzoni MF, Mackie K, Kaneko T, Conrath $M$. CB1-cannabinoid and mu-opioid receptor co-localization on postsynaptic target in the rat dorsal horn. Neuroreport 2001; 12 : 3689-92.

11. Rios C, Gomes I, Devi LA. mu opioid and CB1 cannabinoid receptor interactions: reciprocal inhibition of receptor signaling and neuritogenesis. Br J Pharmacol 2006; 148: 387-95.

12. Wilson AR, Morgan MM. Repeated cannabinoid injections into the rat periaqueductal gray enhance subsequent morphine antinociception. Neuropharmacology 2008; 55: 1219-25.

13. Smith PA, Selley DE, Sim-Selley LJ, Welch SP. Low dose combination of morphine and delta9-tetrahydrocannabinol circumvents antinociceptive tolerance and apparent desensitization of receptors. Eur J Pharmacol 2007; 571: 129-37.

14. Abrams DI, Couey P, Shade SB, Kelly ME, Benowitz NL. Cannabinoid-opioid interaction in chronic pain. Clin Pharmacol Ther 2011; 90: 844-51.

15. Noyes $R \mathrm{Jr}$, Brunk SF, Avery DA, Canter AC. The analgesic properties of delta-9-tetrahydrocannabinol and codeine. Clin Pharmacol Ther 1975; 18: 84-9.

16. Health Canada. Consumer Information - Cannabis (Marihuana, marijuana) - 2013. Available from URL: http://www.hc-sc.gc.ca/ dhp-mps/marihuana/info/cons-eng.php (accessed September 2015).

17. Bisaga A, Sullivan MA, Glass A, et al. The effects of dronabinol during detoxification and the initiation of treatment with extended release naltrexone. Drug Alcohol Depend 2015; 154: 38-45. 